\title{
BIOLOGICAL FARMING IN CONDITIONS OF TRANSFORMATIONAL CHANGES IN THE AGRARIAN PRODUCTION OF UKRAINE
}

\author{
V. F. Petrychenko, O. V. Korniychuk, I. S. Voronetska \\ Institute of Feed Research and Agriculture of Podillia, NAAS \\ 16, Yunosti prosp., Vinnytsia, Ukraine, 21100 \\ e-mail: petrichenko.vasil@gmail.com,o.kornychuk@ukr.net,pirogovo@i.ua
}

Received on August 03, 2018

\begin{abstract}
Aim. To highlight the peculiarities of transformational changes in land use in agrarian production in terms of soil fertility and farming efficiency in Ukraine. To carry out a comparative analysis of the efficiency of use of land resources in different European countries. To substantiate approaches to farming biologization in conditions of intensification of agrarian production and climate change. Methods. Observation, comparison, analysis and synthesis, system analysis and forecast. Results. The results of long-term fundamental and applied researches on the effect of intensification of agriculture on the productivity level of agrarian production have been analyzed. A benchmarking analysis of the efficiency of use of land resources in Ukraine and European countries has been carried out. It has been established that as a result of economic activity the basic principle of interaction between the agriculture and livestock sector was violated, which does not allow to combine effectively and use the intensification factors, the principle of fruit variability is not applied when introducing short crop rotations of the market crops. Conclusions. The effectiveness of agrarian production in conditions of transformational changes depends on the biological farming, which should be targeted at the rational use of land resources, prevention of degradation, preservation and enhancement of soil fertility and sustainable land use in time, use of life factors of agricultural plants taking into account their biological requirements.
\end{abstract}

Keywords: soil resources, intensification, fruit variability, fecundity, fertility, hydro-technical coefficient, agriculture, biologization.

DOI: $10.15407 /$ agrisp5.02.003

\section{INTRODUCTION}

Transformational changes in the structure and functioning of Ukrainian ecosystems had an especially negative effect on the content of organic matter, which serves both as a bioenergetic basis of fertility and a regulator of all the living processes in agriculture. This may be proven by the fact that $600-700 \mathrm{~kg} / \mathrm{ha}$ of humus is lost on average in the country due to erosion by water or wind, and even more so - due to extraction with the harvest of agricultural crops, etc. [1]. The most common alternative method of agrarian production in the world is biological farming, which creates potential possibilities to satisfy the increasing demand of the population for ecologically pure and safe food products.

\footnotetext{
(C) V. F. PETRYCHENKO, O. V. KORNIYCHUK, I. S. VORONETSKA, 2018
}

The introduction of novel achievements of science, engineering and technology enhanced the anthropogenic impact on the environment. The acceleration of the tempo of scientific and technical progress requires a systemic approach to protecting land resources of Ukraine from degradation, and the intensification of agrarian production requires the elaboration of a strategy of adjusting business programs to the principles of agriculture biologization and stability of biosphere as an integral system. Therefore, rational use of land resources, which would ensure high standards of domestic agrarian production without creating any threat of degradation processes, is a relevant economic problem, which requires scientific substantiation.

The aim of the study is to substantiate the specificities of transformational changes in the agrarian production from the standpoint of soil fertility, to establish 
PETRYCHENKO et al

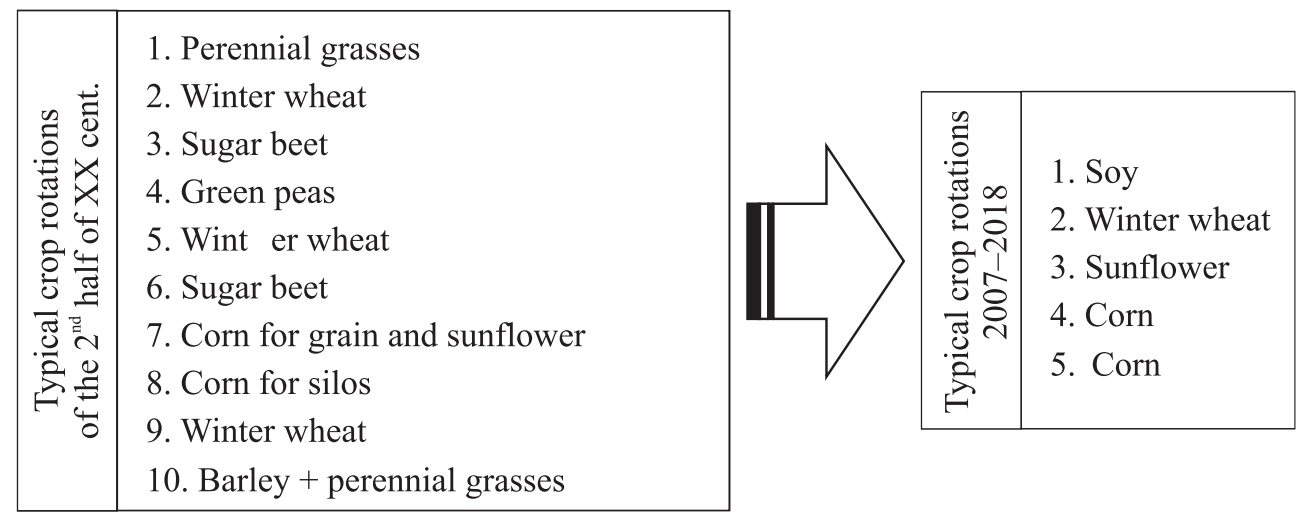

Fig. 1. Transformation of crop rotations in the Right-Bank Forest-Steppe*. *Built by the authors

their impact on the efficiency of Ukrainian agriculture, and to suggest the model of agriculture biologization in climate change conditions.

\section{MATERIALS AND METHODS}

The theoretical and methodological grounds of the study were found in the fundamental laws of ecosystem development, the main principles of economic theory, the articles of domestic and foreign researchers on the issues of efficient land use and agrarian production. The whole world witnesses rapid development of technologies of rational land use. Recently the domestic scientific community has become active in highlighting the issues of extended restoration of soil fertility. Noteworthy are the works of A.S. Baliuk [1, 2], V.A. Velychko [3], H.M. Hospodarenko [4], E.G. Dehodiuk [5], O.O. Ivashchenko [6], V.V. Medvedev [7], V.F. Petrychenko $[9,10]$, V.P. Patyka [11] and many others [12-19]. However, not all the aspects of this problem have been solved in conditions of enhanced intensification in using land resources and increasing the tempo of agrarian production.

The main scientific research methods have been selected as follows: observation - the study of the impact of transformational changes in agriculture on soil fertility, analysis and synthesis - to estimate the efficiency of using land resources in different European countries; comparison and systemic analysis - to conduct benchmarking analysis of the land use in Ukraine and in the EU member-states.

The results of long-term studies of the scientists of the Institute of Feed Research and Agriculture of Podillia, NAAS, and other research centers of Ukraine, perennial observations of the Vinnytsia Branch of the state institution "Institute of Soil Protection of Ukraine", statistical materials of the State Statistics Service of Ukraine, the databases of the European Commission and European countries were used in the article.

Table 1. The dynamics of area under agricultural crops in Ukraine, thous. ha*

\begin{tabular}{|c|c|c|c|c|c|}
\hline \multirow{2}{*}{ Cultures } & \multicolumn{4}{|c|}{ Years } & \multirow{2}{*}{$\begin{array}{c}2017 \text { to } 1990, \\
\%\end{array}$} \\
\hline & 1990 & 2000 & 2010 & 2017 & \\
\hline Total area of the planting, thous. ha: & 32406 & 27173 & 26952 & 27434.3 & 84.7 \\
\hline Grains: & 14583 & 13646 & 15090 & 14104.6 & 96.7 \\
\hline wheat & 7577 & 5619 & 6451 & 6368.3 & 84.0 \\
\hline Grain legumes & 1424 & 408 & 429 & 502.7 & 35.3 \\
\hline Technical crops: & 3751 & 4187 & 7296 & 9161.2 & 244.2 \\
\hline sugar beet & 1607 & 856 & 501 & 318 & 19.8 \\
\hline soy & 93 & 65 & 1076 & 1994.1 & 2144.2 \\
\hline sunflower & 1636 & 2943 & 4572 & 5943.1 & 363.3 \\
\hline rape & 90 & 214 & 907 & 789.1 & 876.8 \\
\hline Forage crops & 11999 & 7063 & 2599 & 1825.5 & 15.2 \\
\hline
\end{tabular}

*Built by the authors using the data [17]. 


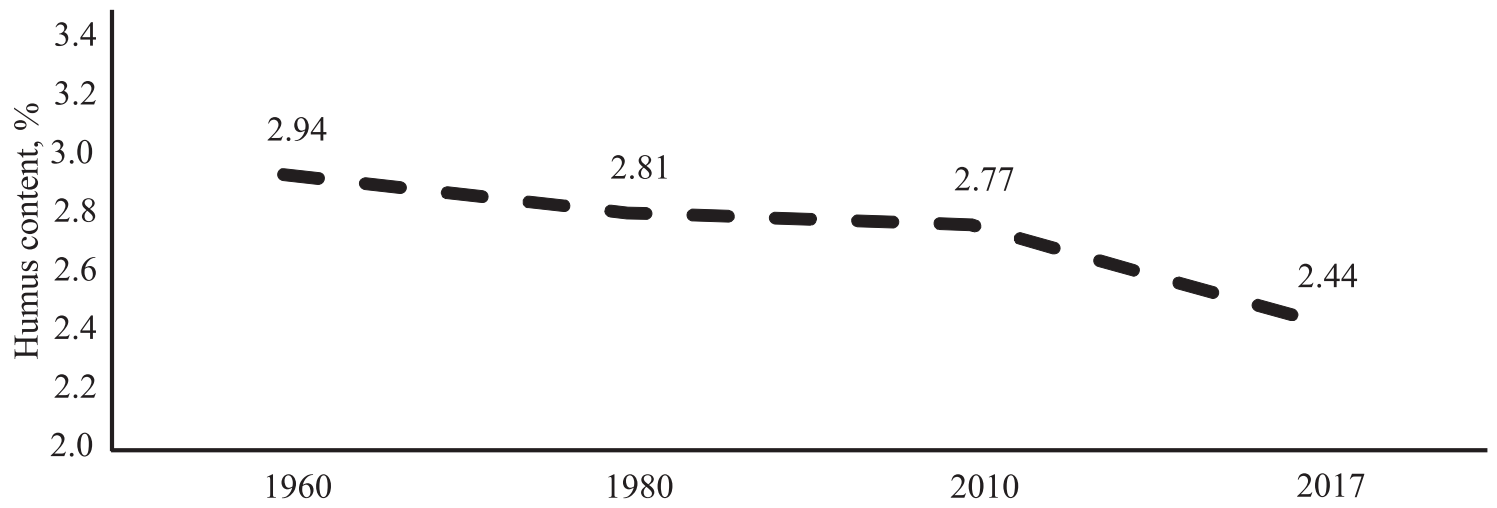

Fig. 2. The dynamics of humus content in agriculture of the Forest-Steppe, $\% *$. *Built according to the data of the Vinnytsia Branch of state institution "Institute of Soil Protection of Ukraine"

\section{RESULTS AND DISCUSSION}

The formation of the performance of grain agrophytocenoses is a complicated multifactor process, depending on many natural and anthropogenic components. At the same time, in conditions of climate change, the system of relations between biological objects and environment, which caused constant serious risks in conditions of agrarian production intensification, is complicated and requires scientific substantiation for stable land use.

There is transformation of crop rotations, where the principle of fruit variability is not always followed while rotating crops in space and time. For instance, multiple field crop rotations in most farms have been transformed into short rotational ones, which are saturated with market-determined crops (Fig. 1).

There is a remarkable almost 3-fold decrease in the area of fields of leguminous crops which are biologizators of agrocenoses. The areas of sugar beet fields have decreased 5 times, whereas the fields of sunflower increased 3.6 times which is $22 \%$ in the structure of area under crops that is 2.5 -fold higher compared to agrobiological and phytosanitary norms (Table 1).

The fields of soy enlarged more than 20 times, and those of rape - almost 9 times. The share of corn in short crop rotations increased up to $40 \%$. At the same time, the fields of grain legumes, perennial and annual grasses as good predecessors of winter wheat decreased 6.6 times i.e. from 37 to $6.6 \%$ in the structure of planted fields. The process of intensification in agrarian production led to diminishing the range of agricultural crops from $10-12$ to $3-4$. As a rule, these are winter wheat, soy, corn, winter rape and sunflower.

Unfortunately, the change in production structure was based only on temporary market-volatile interests not taking into consideration biological, ecological and soil-cenotic consequences, which, as the experience of recent years demonstrates, are negative, enhancing the problematic character of solving the main task of land use - ensuring extended restoration of soil fertility and implementing business programs in agrarian production with high indices of quality and safety.

The analysis demonstrates that a powerful impact on the formation of current short crop rotations was made by massive decrease in livestock in the public sector of the agroindustrial complex. For instance, in 1990 2017 keeping cattle in all the categories of Ukrainian households decreased from 24.6 to 3.5 million heads or almost 7 times. Actual elimination of cattle-breeding at most farms conditioned deep negative changes in current agricultural systems. It also led to a sharp decrease in employment for rural population which is an extremely grave social and economic problem and one of the main reasons of village decay. At present, some of the most urgent problems in the "agriculturelivestock" system are as follows:

there is a decrease in the volumes of production and introduction of organic fertilizers, which had the most negative impact on soils with low humus content and higher acidity, the area of which in the country exceeds 16 million ha;

there has been a sharp reduction in the fields of forage crops, especially perennial and annual leguminous grasses which are effective biologizators;

there has been diversification of using after-harvest plant residues, a larger part of which was used for the production of organic fertilizers. Currently this kind of vegetative production is removed from the field for different purposes, including the production of biofuel, 


\section{PETRYCHENKO et al.}

which leads directly to the impoverishment of soil in organic matter.

On the background of a high level of soil ploughness and removal of organic fertilizers from the fertilization system of agricultural crops, there is a decrease in humus content, especially on gray forest soils which cover over one-third of soils in the region (Fig. 2).

For instance, in 1960-2010 the humus content in the Forest-Steppe decreased by $0.17 \%$, and in 2010 2017 - by $0.33 \%$ which is a convincing proof of the acceleration of soil degradation process. The tempo and direction of the latter is greatly impacted by the intensification of soil processing systems, the level of its ploughness and insufficient substantiation of the structure of fields in short crop rotations. Similar dependences are also remarkable for podzolized chernozem (Table 2).

For instance, long-term land use conditioned the decrease in the humus content in podzolized chernozem without the introduction of mineral fertilizers - by $0.54 \%$, and in case of introducing the medium dose - by $0.27 \%$, whereas annual introduction of $13 \mathrm{t}$ of organic fertilizers per hectare of crop rotation area promoted the increase in this index by $0.28 \%$ and the refusal from the mechanical processing - by $0.92 \%$ which ensures extended restoration of soil fertility [4].

It is obvious that in conditions of intensifying agrarian production where agrobusiness deals with a smaller range of crops one should change traditional approaches to the system of soil processing. Therefore, preference should be given to the systems of self-restoring agriculture with corrections in the system of protecting these crops from harmful objects and the introduction of scientifically substantiated approaches to the biologization of their cultivation.

The presented results of the studies demonstrate a considerable threat of the increase in the ploughness of land without organic and mineral fertilizers, especially in conditions of enhancing the aridity. The reduction of the share of organic fertilizers in the system of fertilization with simultaneous increase in mineral fertilizers, mostly presented by physiologically acid kinds, leads to inevitable increase in the indices of its acidity.

In the opinion of H.M. Hospodarenko and I.V. Prokopchuk, the reduction of the organic matter and the increase in the acidity indices has a negative impact on agrophysical and agrochemical indices of soil. There was a noted deterioration in its structure and a reduction in anti-erosion resistance [18].

It is known that the increase in acidity indices blocks the ability of useful microbiota of soil, which functions only in case of neutral reaction of the soil solution [20]. The observations demonstrate that relative balance in the "plant-environment-pathogen" system shifts towards the latter. There is a sharp increase in fungoid diseases, in particular, in fusarioses, on all the agricultural crops. There is a higher need of increasing the frequency of introducing fungicides, which is an additional load and pressure on ecosystems. At the same time, there is higher frequency and duration of drought which leads to reduced moisture-retaining quality of soil which increases the deficiency of soil humidity $[6,15]$.

Gradually, modern agrophytocenoses develop a situation which reminds an endless circle: reduced plantings of leguminous crops in the transformed crop rotations due to the abovementioned reasons lead to the impossibility of extending them without any additional expenses for melioration even in the presence of implementing this agroevent. The longer the process is, the more complicated its consequences will be. Currently we do not plant leguminous crops, because there is no need of using them, and tomorrow we will not be able to sow them if the need arises. Leguminous crops serve

Table 2. The impact of mineral and organic fertilizers on the indices of humus content and acidity of the soil solution of podzolized chernozem (1964-1998)*

\begin{tabular}{l|c|c}
\hline \multicolumn{1}{c|}{ Experiment variants } & $\begin{array}{c}\text { Humus content in the arable } \\
(0-30) \text { soil layer, } \%\end{array}$ & $\mathrm{pH}(\mathrm{KCl})$ \\
\hline Initial content & 3.40 & 6.2 \\
Crop rotation without fertilizers & 2.86 & 5.2 \\
Introduction of $\mathrm{N}_{90} \mathrm{P}_{90} \mathrm{~K}_{90}$ & 3.13 & 4.7 \\
Introduction of 13 t per hectare of crop rotation area & 3.68 & 5.4 \\
34-year-long fallow & 4.32 & 5.9 \\
\hline
\end{tabular}

*Built using the data [4]. 


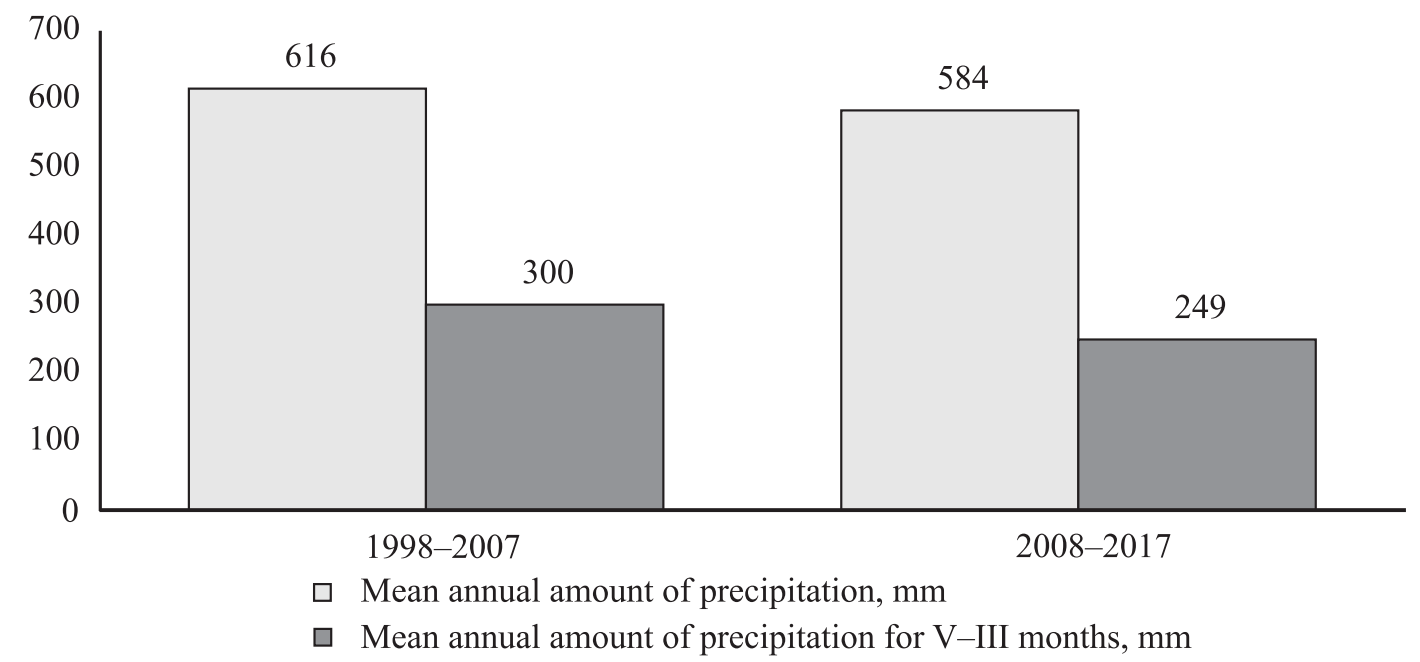

Fig. 3. The dynamics of mean annual amount of precipitation by the vegetation of plants in the Forest-Steppe conditions, mm

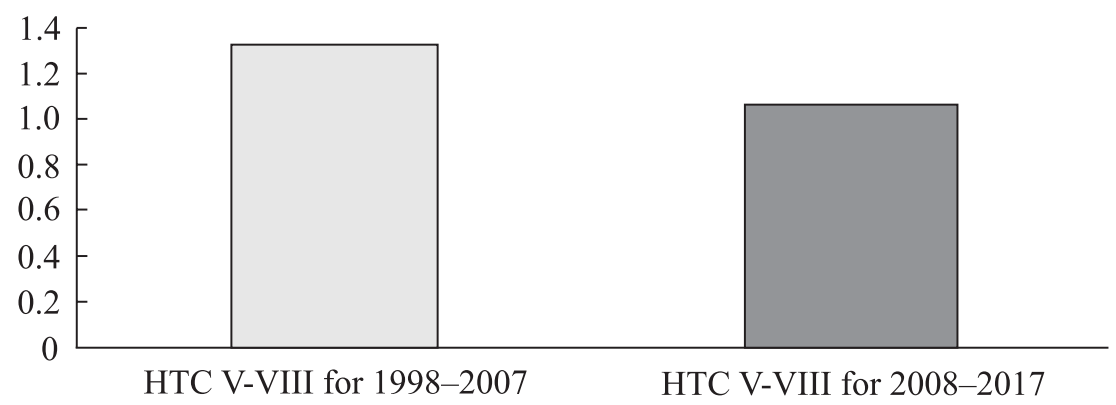

Fig. 4. The indices of the hydrothermal coefficient (HTC)*. *Built using the data of the studies of scientists of the Institute of Feed Research and Agriculture of Podillia, NAAS [19]

as a basis of sustainable use of land resources and ensure extended restoration of soil fertility $[11,16]$.

The second component of global changes in agrophytocenoses, which is extremely important, is a constantly increasing deficiency of moisture provision at the background of considerable warming. Soil moisture is the main limiting factor at all the stages of development of agricultural crops.

The comparison of the main meteorological indices of the recent decade (2008-2017) against the previous one (1998-2007) demonstrated that the total annual amount of precipitation decreased from 616 down to $584 \mathrm{~mm}$ or by $5.2 \%$ including the vegetation period from 300 to $249 \mathrm{~mm}$ or by $17 \%$ (Fig. 3).

Here the sum of active temperatures for the vegetation period increased by $105^{\circ} \mathrm{C}$, and the hydrothermal coefficient (HTC) decreased from 1.36 to 1.06 or by $0.26 \mathrm{~d}$, approximating the indices of the northern Steppe (Fig. 4).

At the same time, the planted areas of agricultural crops which require a considerable amount of soil mois- ture and nutrients have increased rapidly and amount to 60-80 \% in current short crop rotations. For instance, 1 ha of sunflower fields during the vegetation period removes 4-4.5 thousand tons of water from soil, and 1 ton of seeds $-82 \mathrm{~kg}$ of nitrogen, $65 \mathrm{~kg}$ of phosphorus and $186 \mathrm{~kg}$ of potassium [9]. At the same time, during this period on most territories of the Forest-Steppe region there is $249-300 \mathrm{~mm}$ of precipitation, which proves the increased deficiency of productive soil moisture. The estimation of water loss due to evaporation demonstrates obvious formation of moisture deficiency even in case of annual amount of precipitation, exceeding $500 \mathrm{~mm}$. This situation is observed in the Forest-Steppe conditions every 6 years out of 10 .

The noted soil moisture deficiency undermines the efficient application of one of the main intensification factors - the fertilization system, which inevitably leads to the drop in natural soil fertility. In these conditions, the absence or insufficiency of organic fertilizers in the fertilization system becomes especially tangible.

It gives grounds for the situation when the removal of nutrients with the yield of energy-intensive crops 


\section{PETRYCHENKO et al.}

should be compensated with the relevant amount of fertilizers, but the introduction of their required doses is undermined by increased soil acidity and soil moisture deficiency. This approach to the application of land resources entails the threat of their gradual degradation and requires scientifically substantiated approaches to their efficient application, where fertilization systems should involve the use of mineral, organic and bacterial fertilizers, biological growth stimulators, siderates, etc.

As stated above, a considerable threat to preserving land resources is found in the level of their ploughness, especially in case of intense tillage. Unfortunately, the level of ploughness of agricultural lands in Ukraine is the highest in Europe $-76 \%$, whereas in Great Britain $-25 \%$, Germany $-33 \%$, Hungary $-37 \%$, France $-48 \%$ [20].

Soil resources are subject to constant degradation due to erosion by water and wind, conditioned by the intensification of their use. As known, every year over 15 million ha of lands are removed from the farming business annually, including 8 million ha - for the communal needs, 7 million ha - due to degradation. Unfortunately, mankind has already lost over 2 billion ha of fertile lands, these are so called badlands [21]. The scales of soil degradation become oppressive, which is noted by domestic [3, 10, 14, 15] and foreign researchers [22-30].

The use of land resources in Ukraine is inferior to the EU member-states in terms of efficiency (Table 3).

While Ukraine leaves behind Germany, Poland and France by the area of tilled land per caput 5.5 and 2.8 times respectively, the indices of grain production per caput exceed only $2.6,1.8$ and 1.5 times respectively $[28,32]$. This demonstrates the domination of extensive approach over the intense one in the development of grain production of Ukraine. Therefore, a high level of grain production is obtained due to the extension of the share of land resources instead of enhancing the performance of grain crops.

Table 3. The efficiency of using land resources, $2017^{*}$

\begin{tabular}{|c|c|c|c|c|c|c|c|}
\hline \multirow{2}{*}{$\begin{array}{l}\text { European } \\
\text { countries }\end{array}$} & \multirow{2}{*}{$\begin{array}{l}\text { Population, } \\
\text { mln people }\end{array}$} & \multicolumn{2}{|c|}{ Tillage area } & \multicolumn{4}{|c|}{ Produced grain } \\
\hline & & mln ha & per caput, ha & Total, mln t & $\begin{array}{l}\text { per } 1 \text { ha } \\
\text { of grains, } t\end{array}$ & $\begin{array}{l}\text { per } 1 \text { ha of } \\
\text { tilled land, } t\end{array}$ & per caput, $\mathrm{t}$ \\
\hline Germany & 82.5 & 11.8 & 0.14 & 45.9 & 7.31 & 3.89 & 0.56 \\
\hline France & 66.9 & 18.6 & 0.28 & 67.7 & 7.24 & 3.64 & 1.01 \\
\hline Poland & 37.9 & 10.8 & 0.28 & 31.6 & 4.27 & 2.93 & 0.83 \\
\hline Ukraine & 42 & 32.5 & 0.77 & 61.9 & 4.25 & 1.90 & 1.47 \\
\hline
\end{tabular}

*Calculated using the data $[28,31,32]$.

Table 4. The benchmarking analysis of land use in Ukraine and European countries, 2017 *

\begin{tabular}{l|c|c}
\hline \multicolumn{1}{c|}{ Indices } & Ukraine & EU member-states \\
\hline Field area, million ha & 60.4 & 437.4 \\
Area of chernozem, million ha & 28 & 18 \\
Area of agricultural lands, million ha & 42.7 & 178.7 \\
Area of arable lands, million ha & 32.5 & 115.7 \\
Level of ploughness, \% & 76.1 & 65.1 \\
Share of rented agricultural lands, \% & 97 & 53 \\
Area of agricultural lands, certified as organic ones, million ha & 0.3 & 5.3 \\
Area of irrigated lands, million ha & 0.5 & 11.1 \\
Price of investments, thous. \$/ha & 1.0 & 5.5 \\
Export of grains, mln t & 41.8 & 38.5 \\
Area of agricultural lands per one citizen, ha/person & 0.77 & 0.4 \\
Price of agricultural land, thous. \$/ha & 1.2 & 7.2 \\
\hline
\end{tabular}

*Calculated using the data $[17,20,31]$. 
BIOLOGICAL FARMING IN CONDITIONS OF TRANSFORMATIONAL CHANGES IN THE AGRARIAN

\begin{tabular}{|c|c|}
\hline \multicolumn{2}{|c|}{ Factors (reasons) of soil degradation } \\
\hline Anthropogenic impact & Changes of natural character \\
\hline $\begin{array}{l}\text { - Annual ploughness } \\
\text { - Violation of the technology of harvesting } \\
\text { - Burning off stubble } \\
\text { - Acidization and salinization of soil } \\
\text { - Irrational use of pesticides } \\
\text { - Creating industrial disposal and refuse dumps } \\
\text { - Use of large equipment } \\
\text { - Radioactive contamination }\end{array}$ & $\begin{array}{l}\text { - Warming } \\
\text { - Drought } \\
\text { - Storm rainfall } \\
\text { - Snowfall } \\
\text { - Hail } \\
\text { - Glazed frost } \\
\text { - Pests and diseases of agricultural crops }\end{array}$ \\
\hline \multicolumn{2}{|c|}{ Consequences } \\
\hline
\end{tabular}

- Violating the law of returnin g nutrients into soil - change in the number of soil organisms

- Erosion by water and wind

- Increased soil acidity

- Removal of nutrients with harvest and by - products, increased evaporation

- Soil panning, biological contamination of soils

- Elimination of soil organisms in surface layers of soil

- Swamping and salinization of soil

- Changes in soil processes, accumulation of pesticide break - up in the soil system

- Reduction in land resources for agrarian production

\section{Measures for farming biologization}

- Introduction of self - restoring agriculture systems using No-till, Strip-till technology

- Extensive restoration of soil fertility due to active work of microorganisms (mycorrhizal fungi)

- Scientifically - grounded crop rotations and increasing the share of leguminous crops

- Melioration of land resources

- Application of preparations, enhancing the functional activation of soil biota;

- Application of phosphor - mobilizing preparations and preparations of associative nitrogen fixation by nonleguminous crops

- Use of organic fertilizers, siderates, plant residues and destructors

- Adopting the law on preserving soils and protecting their fertility in accordance to the strategy of using land resources and business programs

Fig. 5. The model of biologization for agrarian production in conditions of rational land use*.*Elaborated by the authors

Having the largest area of arable land in Europe, Ukraine produces twice less grain per 1 ha of tilled land compared to Germany, 1.9 times - compared to France, and 1.5 times - compared to Poland. About $6-8 \mathrm{~kg}$ of grain is produced per each unit of the active substance of NPK in Ukraine, whereas in the EU member states this figure amounts to $10-12 \mathrm{~kg}$ and more. The area of chernozem in Ukraine exceeds that of the EU member- states 1.6 times, but it covers $87.5 \%$ of the arable land structure, whereas in the EU member-states this index is only $15.5 \%$ (Table 4).

Regardless of the fact that over $87 \%$ of the land fund of Ukraine are constituted by chernozem soils (against $15 \%$ in the EU member-states), as of January 1, 2018 their price is 6 times lower compared to the EU mem- 


\section{PETRYCHENKO et al.}

ber-states. In case of high tempo of enhancing the frequency and duration of drought periods as well as their extension to traditional zones of sufficient irrigation, the areas of irrigated lands in Ukraine are more than 20 times smaller than those of the EU member-states and constitute only $0.8 \%$, and the agricultural lands, certified as organic ones, $-0.7 \%$.

Ukraine has almost twice smaller level of intensification of land resources compared to the EU memberstates, but exceeds in the level of grain export 1.1-fold which demonstrates that the domestic agrarian production transforms into Europe's source of raw materials.

Therefore, deep changes of both anthropogenic and natural origin have been taking place in Ukraine's agrarian production within recent decades. The cumulative and synergetic impact of these changes has created serious risks in current agriculture systems. This impact has become especially tangible within the recent decade, the most relevant consequences being

- the transformation of multiple field crop rotations into short rotations under the pressure of market-volatile relations. There has been a sharp reduction in the planting area of leguminous crops. There is enhanced intensification of cultivating market crops in short rotations without the preservation of fruit variability;

- the deficiency of soil moisture and growing tendencies to increased acidity of soil undermine the efficiency of one of the main intensification components - fertilization system. The removal of nutrients with the harvest is not completely compensated with their subsequent introduction. The provisions of the law of returning are not followed which leads to the impoverishment of soil in organic matter and their degradation;

- there is a reduction in the yearly amount of precipitation and its amount within the period of active vegetation of plants, an increase in the sum of active temperatures, a decrease in the index of hydrothermal coefficient, which approximates the values, remarkable for the northern Steppe. There is increased loss of soil moisture.

Therefore, domestic agrarian production requires close monitoring in terms of rational land use with the consideration of the experience of the EU memberstates and elaboration of countermeasures to destructive degradation processes. There should be changes to current intensification of agrarian production which in most current cases is not only inefficient, but also loss-making. We suggest a model of biologization for agrarian production in conditions of rational land use (Fig. 5).

The principles of agriculture biologization and biosphere stability as an integral system foresee a systemic approach to selecting the varieties of agricultural crops with high adaptive properties, the introduction of a crop rotation with fruit variability taking into consideration their biological requirements, the cultivation technologies and impact on soil fertility.

Therefore, such agriculture systems should foresee the cultivation of perennial grasses, annual legumegrasses in intermediate plantings similar to No-till technology.

There are changes to the introduction of mineral, organic, and bacterial fertilizers, the principles of adequacy for regulation of harmful objects (pests, diseases and weeds) are implemented to preserve relative balance in the agroecosystems. In biological farming we should view soil in absolutely different light as the main means, as a commodity, and a biological object. Soil, as a living substance in agroecosystems, should have active soil biota.

Therefore, we believe that in the conditions of climate change and taking into consideration biological, ecological, and soil-cenotic processes, current technologies in agriculture are not capable of ensuring the implementation of business programs and extensive restoration of soil fertility.

\section{CONCLUSIONS}

Long-term intensification of agrarian production violated the main principle of interaction between the agriculture and cattle-breeding which does not provide for efficient combination and use of current systems of crop rotations, fertilization, processing, protection, varietal resources and material-technical supply. The evolution of studies proves that the principle of fruit variability is not followed in the transformed crop rotations. In conditions of climate change in the Forest-Steppe there was a noted prolongation of the duration of the vegetation period for 15-20 days, the increase in the sum of positive temperatures by $105-250{ }^{\circ} \mathrm{C}$, the decrease in the index of hydrothermal coefficient up to 1.0 and the amount of precipitation from $616 \mathrm{~mm}$ to $584 \mathrm{~mm}$. Therefore, the biologization of agrarian production should be aimed at rational use of land resources, their protection from degradation, preserving and enhancing soil fertility and sustainable land use in time as well as efficient management of soil biota 


\section{BIOLOGICAL FARMING IN CONDITIONS OF TRANSFORMATIONAL CHANGES IN THE AGRARIAN}

and life factors of agricultural crops with the consideration of their biological requirements.

Біологізація землеробства в умовах трансформаційних змін аграрного виробництва України

В. Ф. Петриченко, О. В. Корнійчук, І. С. Воронецька e-mail: petrichenko.vasil@gmail.com, o.kornychuk@ukr.net,pirogovo@i.ua

\section{Інститут кормів}

та сільського господарства Поділля НААН

пр-кт Юності, 16, м. Вінниця, Україна, 21100

Мета. Висвітлити особливості трансформаційних зміни землекористування в аграрному виробництві з точки зору рівня родючості грунтів та ефективності землеробства в Україні. Здійснити порівняльний аналіз ефективності використання земельних ресурсів в різних країнах Європи. Обгрунтувати підходи щодо біологізації землеробства в умовах інтенсифікації агарного виробництва та змін клімату. Методи. Спостереження, порівняння, аналіз та синтез, системний аналіз і прогноз. Результати. Проаналізовано результати багаторічних фундаментальних та прикладних досліджень щодо впливу інтенсифікації землеробства на рівень продуктивності аграрного виробництва. Проведено бенчмаркінг-аналіз ефективності використання земельних ресурсів в Україні та країнах Європи. Встановлено, що в результаті господарської діяльності порушено основний принцип взаємодії галузі землеробства й тваринництва, що не дозволяє ефективно поєднувати й використовувати фактори інтенсифікації, не дотримується принцип плодозмінності при впровадженні короткоротаційних сівозмін насичених ринковими культурами. Висновки. Ефективність аграрного виробництва в умовах трансформаційних змін залежить від біологізації землеробства, яка повинна бути спрямована на раціональне використання земельних ресурсів, захисту їх від деградації, збереження й підвищення родючості грунтів та сталого землекористування в часі, використанні факторів життя сільськогосподарських рослин з врахуванням їх біологічних вимог.

Ключові слова: грунтові ресурси, інтенсифікація, плодозмінність, родючість, гідротехнічний коефіцієнт, землеробство, біологізація.

\section{Биологизация земледелия в условиях трансформационных изменений аграрного производства Украины}

В. Ф. Петриченко, А. В. Корнийчук, И. С. Воронецкая, e-mail: petrichenko.vasil@gmail.com, o.kornychuk@ukr.net, pirogovo@i.ua

Институт кормов и сельского хозяйства Подолья НААН пр-кт Юности, 16, г. Винница, Украина, 21100
Цель. Осветить особенности трансформационных изменений землепользования в аграрном производстве с точки зрения уровня плодородия почв и эффективности земледелия в Украине. Осуществить сравнительный анализ эффективности использования земельных ресурсов в разных странах Европы. Обосновать подходы к биологизации земледелия в условиях интенсификации аграрного производства, а также изменений климата. Методы. Наблюдение, сравнение, анализ и синтез, системный анализ и прогноз. Результаты. Проанализированы результаты многолетних фундаментальных и прикладных исследований по влиянию интенсификации земледелия на уровень производительности аграрного производства. Проведено бенчмаркинг-анализ эффективности использования земельных ресурсов в Украине и странах Европы. Установлено, что в результате хозяйственной деятельности нарушен основной принцип взаимодействия отрасли земледелия и животноводства, не позволяет эффективно сочетать и использовать факторы интенсификации, не соблюдается принцип плодоизменения при внедрении короткоротационных севооборотов, насыщенных рыночными культурами. Выводы. Эффективность аграрного производства в условиях трансформационных изменений зависит от биологизации земледелия, которая должна быть направлена на рациональное использование земельных ресурсов, защиты их от деградации, сохранения и повышения плодородия почв и устойчивого землепользования во времени, использовании факторов жизни сельскохозяйственных растений с учетом их биологических требований.

Ключевые слова: почвенные ресурсы, интенсификация, плодородие, гидротехнический коэффициент, земледелие, биологизация.

\section{REFERENCES}

1. Baliuk S. Edaphic resources of Ukraine: state and measures on their improving. Visnyk ahrarnoi nauky. 2010; (6):6-7.

2. Baliuk S, Nosko B, Vorotyntseva L. Regulation of fertility of soils and efficiency of fertilizers in conditions of climate fluctuations. Visnyk ahrarnoi nauky. 2018;(4):512.

3. Velychko VA. Ecology of soil fertility. K.: Ahrarna nauka, 2010:274 p.

4. Hospodarenko HM. Fundamentals of integrated application of fertilizers. K.: CLSC Nichlava, 2002;344:4558.

5. Dehodiuk EH, Dehodiuk SE. Ecological-technogenic safety of Ukraine. K.: EKMO, 2006:306 p.

6. Ivashchenko OO., Ivashchenko OO. Ways of adapting agriculture in climate change conditions. Collection of scient. works of NSC Institute of Agriculture of NAAS. Kyiv, 2008:5-21.

7. Medvedev VV, Laktionova LV, Dontsova TN. Aqueous 


\section{PETRYCHENKO et al.}

properties of Ukraine's soils and moisture supply of agricultural crops. Kharkiv, Apostroph, 2011:223 p.

8. Medvedev $V V$. Soil heterogeneity and accurate agriculture. Part 1. Introduction to the problem. Kharkiv: 13 typographia Publishing House, 2007:296 p.

9. Petrychenko VF, Lykhochvor VV. Plant cultivation. Technologies of cultivating agricultural crops. Lviv: NVF Ukrayinski tekhnolohii, 2014:1040 p.

10. Petrychenko VF, Baliuk SA, Nosko BS. Increasing agriculture resistance in global warming conditions. Visnyk ahrarnoi nauky. 2013;(9):5-12.

11. Petrychenko VF, Kaminsky VF, Patyka VP. Leguminous crops and sustainable development of agroecosystems. Kormy i kormovyrobnytstvo. 2003;51:3-6.

12. Kohut BM, Semenov VM. Soil organic matter. M.: GEOS, 2015:233 p.

13. Bohovin A, Ptashnik M. Influence of agricultural measures on ecobiomorphic structure and productivity of self-relative reliable ecosystems on the largest ground lands of forest land. Visnyk ahrarnoi nauky, 2018;(6):128. doi.org/10.31073/agrovisnyk201806-02.

14. Volkogon V, Pyrig O, Brytan T. Directedness of soilmicrobiological processes under the influence of organic and mineral fertilizers. Visnyk ahrarnoi nauky, 2018;(6):5-11. doi.org/10.31073/agrovisnyk201806-01.

15. Hamayunova VV, Fedorovych HT. Agriculture ecologization - the way to restoring soil fertility. Bulletin of Sumy National Agrarian University. Series "Ahronomia i biolohia", 2013; 3(25):64-7.

16. Kaminsky F. Scientific grounds of biological farming in climate change conditions. Collection of scient. works of NSC Institute of Agriculture of NAAS. Kyiv: VP Edelveis, 2016;(1):156 p.

17. Plant production of Ukraine. 2017: statistical compilation. State Statistics Committee of Ukraine. Kyiv. Derzhanalitinform, 2018:222 p.

18. Hospodarenko GM, Prokopchuk IV. Transformation of acid-base properties of the soil for a long fertilizer application in field crop rotation. Bulletin of Uman National University of Horticulture, 2014;(1):8-12.

19. Petrychenko VF, Babych AO, Kolisnyk SI et al. Impact of liming, mineral fertilizers and inoculation on soil fertility and soy performance in the Forest-Steppe conditions. Collection of sci. works of the Institute of Agriculture of NAAS. Kyiv. Nora-print, 2000;(3-4):15-9.

20. Bardgett RD. The biology of soil. A community and ecosystem approach. Oxford University Press, 2005:254 p.

21. Gruver JB. Prediction, Prevention and Remediation of
Soil Degradation by Water Erosion. Nature Education Knowledge, 2013;4(12):2.

22. Jean de la Paix Mupenzi, Lanhai Li, Jiwen Ge, Achal Varenyam, Gabriel Habiyaremye, Nzayisenga Theoneste, Kamanzi Emmanuel Assessment of soil degradation and chemical compositions in Rwandan tea-growing areas. Geoscience Frontiers, 2011;2(4):599-607. doi. org/10.1016/j.gsf.2011.05.003.

23. Gyssels G, Poesen J, Bochet E, Li Y. Impact of plant roots on the resistance of soils to erosion by water: a review. Progress in Physical Geography: Earth and Environment, 2005;29(2):189-217. doi.org/10.1191/0309133305pp443ra.

24. Thompson LM, Trou FR. Soils and their fertility. M.: Kolos, 1982:460 p.

25. York LaM, Carminati A, Mooney SJ, Ritz K, Bennett MJ. The holistic rhizosphere: integrating zones, processes, and semantics in the soil influenced by roots. J. Exp. Bot., 2016;67(12):3629-43. doi:10.1093/jxb/erw108.

26. Friedrich T, Derpsch R, Kassam A. Overview of the Global Spread of Conservation Agriculture. Field Act. Sci. Rep. 2012;(6):1-7.

27. Agriculture, forestry and fishery statistics: 2017 edition. Luxembourg: Publications European Union, 2017:177 p.

28. Report and recommendations on organic farming. USDA. Washington DC: USA, 1980:94 p.

29. Status of the World's Soil Resources. Main Report. Food and Agriculture Organization of the United Nations. Rome, Italy, 2015:608 p.

30. LUCAS - The EU's land use and land cover survey. Eurostat. Luxembourg: European Union, 2017.

31. Denmark's Report for the State of the World's Biodiversity for Food and Agriculture. The Danish AgriFish Agency. The State of the World's Biodiversity for Food and Agriculture in Denmark. 2016:43 p.

32. Kopilov EP. Soil fungi as biotic factor of influence on plants. Silskohospodarska mikrobiologia, 2012;(15-16): 7-28.

33. Khaziev FKh. Methods of soil enzymology. M.: Nauka, 2005:252 p.

34. Povkh OV, Merlenko IM. State of microbiocenosis of turfpodzolic sandy soil under the impact of organic fertilizers and microbiological preparations. Bulletin of the Sumy National Agrarian University. Series "Ahronomia i biolohia", 2013;3(25):61-4.

35. Nadtochiy $P$, Trembitsky $V$. Acid-base buffering capacity and the liming of acid soils in Polissya: actual problems of agroecology. Visnyk DAU, 2003;(2):3-17. 